УдК 130.2:304.4](4)

D.U. Zhyvohliadova, student

Taras Shchevchenko National University of Kyiv 60, Volodymyrska Street, Kyiv, 01033, Ukraine darynazhivog@gmail.com

\title{
EUROPEAN CULTURAL POLICY AND CULTURE MANAGEMENT DEVELOPMENT OF A COMMON EUROPEAN CULTURAL SPACE
}

\begin{abstract}
The article analyzes the potential of interaction between policy and management in the field of culture based on the experience of organizing and implementing cultural projects by the European Union. The purpose of the article is to analyze the EU experience in organizing and implementing the policy of developingthe common cultural space. Historical, systematic, comparative and typological methods of analysis are used. The main conclusions are: European Union culture managerial experience demonstrates certain productive results as well as the possibilities of optimizing the activities of the relevant institutes, methods and mechanisms for the implementation of cultural policy. This productivity is determined by an effort to maintain a correlation between the theoretical and practical levels of political activity in the field of culture and, therefore, through specific programs, to support and develop all sectors of culture.

Key words: European Union, cultural policy, management, cultural space, cultural programs.
\end{abstract}

Formulation of the problem. The modern stage of the cultural and civilizational development of mankind is characterized by the dynamization, complication and diversification of the interaction of cultures. The problem of constructive dialogue becomes the main issue in the international arena, especially at a time when not only the sustainable development of the earth community, but also its physical and spiritual survival as a whole, is emerging. At the same time, researcher of European cultural policy Anthony Everit notes: "The basis of state governance of European countries is a contradiction. It stands in a huge gap between word and deed. All states are constantly making statements about the importance of cultural policy, but these statements are not supported by affairs. The Ministry of Culture or other agencies that manage culture, even if there is generous funding and constant effort, can not change the social priorities. Despite the best intentions, the achievements of cultural policy are insignificant, and if we speak about its implementation, it is even questionable. It is believed that most citizens still do not have a clear idea of what the intentions and goals of their governments in this area "[1]. The creation of a common European humanitarian space is possible with a clear vision of key strategies and models of cultural policy. It implies the existence of a developed cultural discourse on the potential of interaction between policy and management in the field of culture at both global and regional levels (for example, the experience of organizing and implementing cultural projects of the European Union).

Analysis of research and publications. The subject of European integration in cultural policy is new and not so well-known, especially in European practices and principles of governance in this area, as well as international cooperation that directly or indirectly influences the democratization of public administration in the cultural sphere. The search for the definition of cultural policy is characterized by attempts to combine the multiplicity of understanding of culture as a philosophical category and as a type of practical activity. "There is a fundamental difference between the way in which cultural policy is determined at the theoretical and methodological level, and the way it is determined at the level of specific management decisions. These are not only different conceptual but even different subject areas. The level of theoretical generalizations opens up new conceptual possibilities and allows us to formulate new strategic goals, while the "managerial" definitions, which contain more tactical components answer the question of how, with whom and with the help of which resources cultural policy can be implemented "[1]. Ignoring conceptual approaches leads to significant differences in the choice of objects, goals and methods of implementing cultural policy. And, ultimately, the serious consequences in social relationships within society. In the Ukrainian scientific thought, the issues of public administration, its mechanisms and the realities of managerial practice are actively being developed (V. Bakumenko, A. Degtyar, O. Zabuzhko, Y. Kovbasyuk, A. Kolodiy, V. Knyazev, V. Martynenko, N. Nizhnik, G. Odintsova, M. Pasechnik, Yu. Rymarenko, V. Troshchinsky, Y. Sharov, etc.). Culture as the basic factor of social development, strategies and mechanisms of Ukrainian cultural policy in the situation of modern civilizational challenges are analyzed in the studies of V. Andrushchenko, J. Bezvershuk, Y. Bogutsky, O. Valevsky, T. Kovalchuk, M. Loguunova, L. Novohatko, T Shinkarenko, N. Yakovenko.

The purpose of the article is to analyze the EU experience in organizing and implementing the policy of developing a common cultural space.

Main research. Modern space of realization of the European cultural policy with the corresponding strategies and methods of management and managerial activity is a space of postindustrial society with characteristic tendencies of both internationalization of culture and processes of globalization. In addition, it is a society based on the knowledge of the prevalence of information technology. In this new world, cultural policy actors - cultural managers, fundamentally change. For cultural policy of most European countries in recent years, the desire to achieve common goals, namely: support for cultural identity, cultural diversity, creative activity, participation of citizens in cultural life, stands up as the main issue. In addition, the circle ofstakeholders in the cultural and political life is expanding and diversifying considerably. The state ceases to be the only determinant of cultural policy. But there is a large number of other actors whose interests are essential in cooperation and peaceful coexistence.

Modern processes of cultural transformation and the preservation of the human potential of social development necessarily demand the availability of political tools, both at the theoretical and methodological levels. From this point of view, the most productive was the instrumental approach to cultural and political activity (the development and implementation of which began at the intersection of 80-90 centuries of the last century) with its principles of decentralization, finding and stimulating new actors of cultural life. Nowadays, the huge amount of actors from both the private and public sectors of management and economics, who are not directly related to culture, is becoming more and more active on cultural arena. "Politicians and artists are interested in the prospects of investment in culture. It turned out that the revival of cultural activity contributes to social and economic development and prosperity. This was recognized in the reports of UNESCO (Our Creative Diversity, 1996) and the Council of Europe ("The Aspiration for Integrity", 1997), according to a study by a number of countries, including France and the United Kingdom. These documents opened a new era and contributed to the emergence of the concept of culture as a push to development of society. In the simplest approximation, this implies the 
use of culture to achieve goals that are not directly related to it - for example, the use evenings for adults to promote a healthy lifestyle. But the further analysis shows that any cultural activity and, accordingly, any investment in culture have an inevitable socio-economic effect and go for the benefit of society as a whole "[3].

But this situation does not always exist to understand the importance of creating a common European cultural space. For most of the history of the European Union, this was seen as an addition to the problems of economic, political, defense, etc. Issues arising in the cultural sphere were not given proper importance, despite the adoption in 1954 of the European Cultural Convention, which proclaimed the need "... to take appropriate measures to protect the cultural heritage of Europe and to ensure proper access to cultural and artistic objects [2]. Understanding the role of culture and the need for cultural integration has grown only with the gradual shift of priorities of social development from purely economic to political and socio-cultural.

The formation of principles and principles of cultural policy of the European Union had a preliminary history of awareness of the importance of the cultural factors of strategic development of both individual countries and their associations. Although the approval of the need for joint action within the economic union of six European countries took place in 1951-1958, the first steps (in the form of a plan of cultural activities of the European Commission) in the field of cultural and political activities were made only in 1977. The common humanitarian space of the European countries begins to be built by combined actions of the European Social Fund and the European Regional Development Fund, which provided financial support for various cultural events (including literary translations, creative scholarships, etc.), then the 1989 Directive "Television without Frontiers" launched policy of "common market of television broadcasting."

Since the signing of the Maastricht Treaty (1992), cultural policy has become one of the main activities of the European Union. For example, Article 128 defines the duties and powers of the community in the field of the protection of a common European heritage (1992), which necessitates the support of regional and national diversity [65]. The Amsterdam and Lisbon treaties $(1997,2007)$ fixed the enlargement of the EU and the orientation of most of its members to the creation of a federative union formed by countries and peoples with varying degrees of cultural and economic development. These documents, along with the Maastricht Treaty, reveal two areas of European integration, which have internal contradictions. On the one hand, the continental institutional tradition of European federalism with an appropriate system of supranational institutions, and, on the other hand, an attempt to preserve national identities and sovereignties, favoring intergovernmental cooperation [5, p. 141].

The crisis of the European economy against the backdrop of the complication of globalization challenges of cultural identity urgently raised the question of forcing the creativity of culture capital. "Crisis" management and marketing technologies become an integral part of the entire management system of culture and cultural industries. The understanding of culture as the main instrument of spiritual, social and economic revival of regions (European in particular), countries, cities and settlements becomes common. Accordingly, there is a growing need for accumulation of new management experience, which, using the creative potential of cultural democracy, the decentralization of power of subjects of cultural policy, would contribute to the functioning of society as a socio-cultural organism with a high level of appropriate self-organization and positive dynamics of development.
Development of a common European cultural space takes place at various functional levels of intercultural cooperation, coordination of national and cultural policies. Actions are being implemented, activities of scientific institutions, informational and artistic centers of European cultures are being organized, and their effectiveness is being monitored. In practice, the EU cultural policy strategy is implemented in a large number of programs with crosssectoral trends in intercultural development. These programs are aimed to involve both countries-participants, candidate countries, and third countries. So, since the beginning of 1992, the European Union's cultural programs, initiated by the EU Council and the European Parliament: Ariane, Kaleidoscope, Raphael, began to operate. These programs aim at improve knowledge of the culture and history of Europe, promoting artistic creation and exchange in the field of culture, preserving cultural heritage and promoting cultural dialogue and cooperation between the European Union and third countries. Subsequently, the existing projects merged into a single integrated program called "Culture". The program involved activities of the member states of the European Union in the following directions: preservation of the European cultural heritage, support of the national market of cultural values and the culture industry, social support of cultural workers, as well as encouragement of creativity and participation in cultural life. Thousands of organizations are constantly cooperating in the development, selection and accumulation of new cultural forms and technologies, ways of organizing socio-cultural activities that have proven to be most effective and acceptable in terms of improving social organization, development of tools for regulating joint actions, mechanisms for information exchange and social broadcasting.

In 2009, Poland and Sweden launched the idea of creating an "Eastern Partnership" within the EU. The striking goal of the Eastern Partnership was the cooperation of the EU countries with the following countries: Azerbaijan, Belarus, Armenia, Georgia, Moldova and Ukraine (and between themselves). These contacts are supposed to develop both bilaterally and multilaterally in order to bring all spheres of society's life (economics, legislation, management, medicalservices, education, and culture) to the level of European standards. The organization of the Eastern Partnership's activities is carried out at the level of heads of the respective states and governments, foreign ministers of the participating countries. The establishment of common benchmarks for cooperation are devoted to sectoral conferences and thematic platforms. The activity of the main directions of the joint work, the strategies and tasks are fixed in certain programs. In our opinion, the thematic platform No. 4 "People-to-people contacts" is particularly interesting: this platform is established to discuss and solve the problems of the cultural policy of the Eastern Partnership countries, to promote the implementation at the regional levels of the UNESCO Convention on the Protection and Promotion of the Diversity of Cultural Expressions. For this purpose, numerous seminars, conferences, round tables are organized. Also, at regular meetings, the issues of the Eastern Partnership Cultural Program and the EU's Creative Europe program 2014-2020 are discussed. The organization of activities (assigned to the European Commission and the state authorities of the participating countries) takes place in accordance with the Work Program approved for a certain period.

The third millennium opened a new stage in the humanitarian strategy of the European Union, when it was tasked with building a competitive knowledge-based ("Lisbon Strategy", 2000). After the results of this "knowledge 
economy" program in 2005 were reviewed by the European Council, a new edition of the Lisbon program was developed. The correction of plans and activation of activities have led to positive changes, first of all - towards creating a favorable innovation climate, improving education policy, developing information technologies, modernizing the European model of social security. In a joint report of the German insurance group Allianz and the Lisbon Council, it was noted that the EU-25 countries managed to make a significant progress in implementing the Lisbon Strategy. At the same time, Sweden, Belgium and the Netherlands showed the best results.

The peculiarity of the cultural mission in creating a single European humanitarian space at the organizational and political level is, in principle, subsidiarity, which defines the competence of the EU as a community with the relevant government institutions and the legislative system. Due to the understanding of culture as a national, ethnic and regional phenomenon, and as a consequence, cultural policy is a sphere of competence and responsibility primarily of national authorities of the EU member states. The European Union's activities in this area are complementary and integrated, promoting the exchange of experience. Recognition of the value of culture is combined with the understanding of cultural diversity and its forms of expression. This was fixed on November 16, 2007 in the Resolution of the Council of Europe, which emphasizes the "multi-lingual" feature of culture.

In addition, support for various forms, institutions and carriers of national identity, including traditional arts, museums, theaters, libraries, is encouraged among the European Union member states at the international and regional levels. Each country defines its own priorities. In many countries, various institutions that have the status of "national" receive special attention and budget funding. Cultural diversity, national identity and cultural heritage are actively promoted at the international level. For this purpose, special institutes with broad areas of activity, such as the Alliance Française, the British Council, the GoetheInstitut, the Polish Institute, etc. have been established.

The experience of the European Union justify that the effectiveness of cultural policy depends directly on the quality of managerial efforts, which include, in particular, the selection of such forms and mechanisms that are most appropriate for their social cost and results. This social price is determined by the ability to raise the level of mutual understanding and consolidation of the members of the European community (which, as the current realities prove, is becoming an increasingly complex problem.) In order to implement such socially significant intellectual and practical actions of the EU, the abovementioned institutes are established, whose activities are aimed at popularizing European values, languages and cultures.

The priorities of European Union cultural policy are sensitive to the current state of culture. Therefore, among the main priorities of the EU's cultural policy is the support and development of information space and technology. Indeed, about $80 \%$ of the annual budget of the European Commission is aimed at implementing EU programs and projects in this area.

EU information policy, starting in 1994, was aimed at the formation of an information society, the foundation of which was the process of European integration. For the first time, the doctrine of the creation of the European Information Society was announced by Martin Bangemann, who at that time was the Commissioner for Internal Market and Industry. ("Europe and the Global Information Society: Recommendations for the European Union").

It is clear that the creation of an information society can not happen in itself. After all, it should be associated with ensuring the implementation of a number of conditions: economic stability of European countries and the economic growth of traditional and new information industries. In addition, the creation of an information society is directly related to the solution of social problems and providing equal access to global network structures. This applies to systems such as education, administrative management and healthcare.

Such an issue as the development of the common information space should be solved on a modern theoretical basis. Information integration is realized on the basis of the concept of a unified general information policy of the European Union. And only on this theoretical basis of strategies, programs and projects of intergovernmental regional organizations such as telecommunication networks and information communication highways are being implemented.

In 1994, the European Commission adopted a program document entitlEurope's way to the Information Society".This document defines the principles of the EU's activities in the field of information and communication. First, they emphasize the need to prepare the European community for realizing the realities of the information society, emphasizing the importance of shaping public opinion. Secondly, these principles emphasize the importance of creating concepts both European information policy and European information law. Finally, the principles of EU activity in the field of information and communication are thefollowing: providing free access to information services and popularization of such values as preservation of national identity, cultural identity and multilingualism. These principles, as we see, reflectnew trends in the evolution of information and communication development. It is also necessary to mention that information policy has become an instrument for implementing the policy of states, their internal and external political courses.

EU structures and bodies specializing in information policy development have their own institutions, by which the EU implements a general policy on information and communication. These institutions are: the European Council, the European Commission, the General Directorate for Information Society; General Directorate for Education and Culture and EU Information Society Forum. Implementation of EU information and communication policy is also being implemented through information centers in member countries [4].

Nowadays theunderstandingof the appropriate model of cultural policy and culture is changing. The modern author's interpretaion of socio-cultural transformations is the concept of "creative management". If you use the language of management, this means (according to Ritwy Mitchell's definition) that "management is carried out through network structures, forums, institutions and administrative systems, which does not necessarily meanbureaucratic style of policy implementation, but involves flexibility and openness for the further innovations"[1].

This point of view shows that the promotion of cultural policy should be accompanied by the development of new concepts for managing the field of culture. This is proved by the experience of the European Union's cultural and political activities

Conclusion. The UNESCO Charter emphasizes that peace and the protection of human dignity are possible not mostly by the unity of political and economic interests, but much moral and intellectual solidarity. According to this, the future of mankind depends not only on economic capital or natural resources, but also on the collective ability to understand and anticipate changes in the surrounding social, cultural and natural environment - through education, research and knowledge sharing.

The leading role in the organization, coordination, dissemination and strengthening of the international dialogue of cultures and civilizations belongs to the EU institutions such as the European Commission and the European Parliament. Their leadership within the framework of cultural 
policy determines the strategies and priorities for development in the spheres of information, social communication, education, science and culture, with a focus on achievement of real results in international cultural understanding and recognition of the originality of different peoples, which, in turn, is impossible without a profound knowledge of the culture and the society of their own people.

Over the past decade, the very nature of cultural management has changed significantly. It becomes transprofessional, innovative, with network activity and partnership as the main management method (the shift from strict administration and market relations tothe interaction for satisfaction of both general and personal interests). Itprovides conditions for further successful activities in various spheres in order to implement the concept of "creative management" in practice.

Consequently, the managerial experience of the European Union in the field of culture demonstrates certain productive results as well as the possibilities of optimizing the activities of the relevant institutes, methods and mechanisms for the implementation of cultural policy. This productivity is determined by an effort to maintain a correlation between the theoretical and practical levels and, therefore, through specific programs, to support and develop all sectors of culture.

Д. Ю. Живоглядова, студентка філософського факультету Київський національний університет імені Тараса Шевченка, вул. Володимирська, 60, м. Київ, 01033, Україна

\section{REFERENCES / СПИСОК ВИКОРИСТАНИХ ДЖЕРЕЛ}

1. European cultural convention.Article 5. [Elektronnyi resurs]: - Retrieved from http://echr-base. ru/kultura.jsp

2. Kulturnaia polytyka [Electronic resourse] -Retreived from http://www.lomonosovfund.ru/enc/ru/encyclopedia:01302:article?vnum $=27500$

3. Makarenko A. Yevropeiska informatsiina polityka / A.le.Makarenko. K.: Nasha kultura i nauka, 2000. $-368 \mathrm{p}$

4. Shore C. Building Europe: The cultural politics of European integration / C. Shore. - London and New York, Routledge, 2004. - 258 p.

5. Vostriakov. L. Kulturnaia polytyka: kontseptsyy, poniatyia, modely. [Electronic resourse] / L. Vostriakov. - Retrieved from http://www.cpolicy.ru/analytics/80.html

\section{REFERENCES (APA)}

1. European cultural convention.Article 5.Retrieved from http://echrbase.ru/kultura.jsp

2. Kulturnaia polytyka. Retreived from http://www.lomonosovfund.ru/enc/ru/ encyclopedia:01302:article?vnum $=27500$

3. Makarenko, A. (2000). Yevropeiska informatsiina polityka . Kyiv, Nasha kultura i nauka.

4. Shore, C. (2004). Building Europe: The cultural politics of European integration. London and New York, Routledge.

5. Vostriakov, L. Kulturnaia polytyka: kontseptsyy, poniatyia, modely. Retrieved from http://www.cpolicy.ru/analytics/80.html

Received Editorial Board 30.09.18

У статті проаналізовано потенціал взаємодії політики та менеджерської діяльності в сфері культури на основі досвіду організації та реалізації культурних проектів Єөросоюзу. Мета статmі - аналіз досвіду ЄС з організації та реалізації політики створення спільного культурного простору. Застосовуються історичний, системний, компаративний та типологічний методи аналізу. Основними висновками є: менеджерський досвід Європейського Союзу в сфері культури демонструє певні продуктивні результати, а також можливості оптимізації діяльності відповідних інститутів, способів і механізмів впровадження культурної політики. Ця продуктивність визначається намаганням підтримувати кореляцію теоретичного і практичного рівнів політичної діяльності в сфері культури $і$, за рахунок цього, через конкретні програми, підтримувати і розвивати всі сектори культури. Досвід культурно-політичної діяльності ЄС засвідчує, що просування культурної політики повинно супроводжуватись розробкою нових концепцій управління сферою культури. Досвід Євросоюзу засвідчує, наскільки ефективність культурної політики безпосередньо залежить від якості менеджерських зусиль, які передбачають, зокрема, відбір саме таких форм і механізмів, які є найбільш прийнятними за своєю соціальною ціною і результатами. Ця соціальна ціна визначається спроможністю підвищувати рівень взаєморозуміння і консолідованості членів європейської спільноти, що, як засвідчують сучасні реалії, стає все більш складною проблемою. Майбутнє людства, окремих націй і народів залежить не тільки від їх економічного капіталу або природних ресурсів, а й від колективної здатності розуміти й передбачати зміни в навколишньому соціальному, культурному і природному середовищі - за допомогою освіти, наукових досліджень та обміну знаннями.

Ключові слова: Європейський Союз, культурна політика, менеджмент, культурний простір, культурні програми.

Д. Ю. Живоглядова, студентка философского факультета

Киевский национальный университет имени Тараса Шевченко,

ул. Владимирская, 60, г.Киев, 01033, Украина

ЕВРОПЕЙСКАЯ ПОЛИТИКА И МЕНЕДЖМЕНТ В СФЕРЕ КУЛЬТУРЫ. СОЗДАНИЕ ОБЩЕГО ЕВРОПЕЙСКОГО КУЛЬТУРНОГО ПРОСТРАНСТВА

В статье проанализирован потенциал взачмодействия политики и менеджерской деятельности в сфере культуры на основе опыта организации и реализации культурных проектов Евросоюза. Цель статьи - анализ опыта ЕС по организации и реализации политики создания общего культурного пространства. Применяются исторический, системный, компаративный и типологический методы анализа. Основными выводами являются: менеджерский опыт Европейского Союза в сфере культуры демонстрирует определенные продуктивные результаты, а также возможности оптимизации деятельности соответствующих институтов, способов и механизмов внедрения культурной политики. Эта производительность определяется попыткой поддерживать корреляцию теоретического и практического уровней политической деятельности в сфере культуры и, за счет этого, через конкретные программы, поддерживать и развивать все сектора культуры.

Ключевые слова: Европейский Союз, культурная политика, менеджмент, культурное пространство, культурные программы.

удк 008:7.097

М. І. Коробко, канд. філос. наук, старший викладач, Національна академія СБУ,

вул. М. Максимовича, 22, м. Київ, 03022, Україна margarytakorobko@gmail.com

\section{ПЕРЕОСМИСЛЕННЯ РОЛІ ТЕЛЕСЕРІАЛІВ: РОЗВАЖАЛЬНИЙ КОНТЕНТ, ЗАСІБ ПРОПАГАНДИ ЧИ НОВИЙ МІФ}

У статті дається загальний огляд проблеми телесеріалів як явища масової культури. Метою статті є спроба переосмислення ролі телесеріалів у сучасному соціокультурному просторі, визначення їхньої ролі для людства загалом та означення шляхів подальших наукових досліджень у цій сфері. Під масовою культурою ми розуміємо дуже широкий спектр феноменів та явищ, які оточують людину кожного дня, особливо це стосується сфери людського дозвілля. $Є$ різні форми дозвілля: прогулянки, читання, перегляд серіалів тощо. Сьогодні ми можемо говорити про телесеріали як про культурне явище, що не може залишатися поза увагою академічних 